\title{
Telaah Kasus Sengketa Hasil Pilkada Depok Dalam Perspektif Yuridis
}

\author{
Ni'matul Huda
}

\begin{abstract}
Abstrak
Cases related to the Election of the Head of Regent in Depok bestows a significant lesson for all of us, particularly to the District Election Committee. The involvement of law and politics are very dominant on the Election. Consequently, the District Election Committee and Commission of District Watch are demanded to be professional, because if there is a dispute in the future the credibility of the Commission of District Election is going to be that is at stake.
\end{abstract}

\section{Pendahuluan}

Pemilihan kepala daerah secara langsung yang sudah dimulai bulan Juni 2005 merupakan penjabaran ketentuan datam UUD 1945 hasil perubahan keempat yang menyatakan bahwa gubernur, bupati, dan walikota, masing-masing sebagai kepala pemerintah daerah provinsi, kabupaten, dan kota dipilih secara demokratis (Pasal 18 ayat (4)). Cara demokratis itu diterjemahkan ke dalam UU No. 32 Tahun 2004 tentang Pemerintahan Daerah dengan memberikan kesempatan yang seluas-luasnya kepada masyarakat untuk memilih kepala daerahnya secara langsung.

Pemilihan kepala daerah secara langsung memang belum pernah kita lakukan, baik pada masa Orde Baru (UU No. 5 Tahun 1974) maupun pasca Orde Baru (UU No. 22 Tahun 1999). Ketika berlangsungnya UU No. 5 Tahun 1974, sesungguhnya DPRD tidak pernah memiliki hak untuk memilih kepala daerah dan wakil kepala daerah, karena hal itu merupakan hak prerogatif presiden. DPRD hanya memilih bakal calon kepala daerah dan wakil kepala daerah, untuk selanjutnya dimajukan kepada presiden dan presiden yang akan menentukan pilihannya (lihat Penjelasan Pasal 15). Perubahan baru terasa ketika berlakunya UU No. 22 Tahun 1999, dimana DPRD dapat secara langsung memilih kepala daerah dan wakil kepala daerah, dan presiden mengesahkan hasil pemilihan tersebut. ${ }^{1}$

UU No. 32 Tahun 2004 memberikan kesempatan yang luas kepada masyarakat untuk memilih kepala daerah dan wakil kepala daerah secara langsung, tetapi ternyata UU No. 32 Tahun 2004 banyak mengandung cacat yuridis sejak kelahirannya - kalau tidak disebut amburadul - dan high cost. Mengapa

${ }^{1}$ Meskipun dalam praktek terjadi Presiden Megawati menganulir hasil pilihan DPRD, sebagai contoh misalnya terpilihnya Alzier T. sebagai Gubernur Lampung. 
demikian? Karena sejak kelahirannya UU No. 32 Tahun 2004 sudah ditentang oleh sejumlah kalangan LSM dan KPUD sehingga sampai ke meja Mahkamah Konstitusi (MK) untuk diuji secara materiil.

Pada tanggal 22 Maret 2005, telah dikeluarkan putusan MK atas tiga permohonan hak uji materiil UU No. 32 Tahun 2004 tentang Pemerintahan Daerah yang diajukan Centre for Electoral Reform (CETRO), Jaringan Masyarakat Pemantau Pemilu Indonesia, Jaringan Pendidikan Pemilih untuk Rakyat, Aliansi Masyarakat Sipil untuk Demokrasi, Indonesia Corruption Watch (ICW), dan 15 KPUD. Putusan MK intinya menyatakan sebagai berikut: ${ }^{2}$ Pertama, Asas Pilkada sama dengan asas Pemilu, tetapi Pilkada bukan pemilu. Kedua, Pasal 57 ayat (1), menyatakan bahwa KPUD tidak bertanggungjawab kepada DPRD tetapi langsung kepada rakyat. KPUD hanya melaporkan pelaksanaan Pilkada kepada DPRD. Ketiga, Penjelasan Pasal 59 ayat (1), Parpol/gabungan parpol yang tidak memiliki kursi di DPRD, tetapi memiliki suara 15 persen dari hasil Pemilu DPRD bisa mengajukan pasangan calon kepala daerah dan wakil kepala daerah. Keempat, Pasal 66 ayat (3) huruf e, KPUD tidak bertanggungjawab kepada DPRD. Kelima, Pasal 67 ayat (1) huruf e, KPUD tidak perlu mempertanggungjawab penggunaan anggaran kepada DPRD. Keenam, Pasal 82 ayat (2), DPRD tidak bisa menjatuhkan sanksi pembatalan calon.

Keputusan MK sebagian nampak membingungkan, diakui bahwa asas Pilkada sama dengan asas pemilu tetapi Pilkada bukan pemilu. MK menolak uji materi terhadap Pasal 1 Ayat (21) tentang KPUD sebagai pelaksana Pilkada, tetapi mengabulkan Pasal 57 ayat (1) dan Pasal 67 ayat (1) huruf e. MK tidak berusaha menyambungkan kembali hubungan hierarki antara KPU dengan KPUD, mengingat KPUD dibentuk dan disahkan oleh KPU sebagaimana diatur dalam UU No. 12 Tahun 2003. MK justru membuat norma baru dalam putusannya, dimana KPUD tidak bertanggungjawab kepada DPRD tetapi langsung kepada rakyat. Satu sisi MK telah memutus belenggu parlemen lokal terhadap KPUD sebagai penyelenggara Pilkada, tetapi di sisi lain MK tidak menjelaskan siapa yang dimaksud "rakyat" itu serta bagaimana mekanisme pertanggungjawabannya. MK memberi petunjuk bahwa dalam melaksanakan tugasnya KPUD mengacu pada PP No. 6 Tahun 2005 tentang Pemilihan, Pengesahan, Pengangkatan, dan Pemberhentian Kepala Daerah dan Wakil Kepala Daerah. Putusan MK ini oleh sebagian kalangan dinilai "banci" ${ }^{\text {" dan }}$ menjadi seperti "bola tanggung" dalam mengawal demokrasi. ${ }^{4}$

Pertanyaan akademis berikutnya, dapatkah MK dalam memutuskan permohomam uji materiil "membuat" rumusan pasal baru? Apakah dengan keputusan MK tersebut DPR perlu melakukan legislatif review? Ataukah keputusan MK secara otomatis telah berlaku menggantikan rumusan pasal yang telah dibatalkan oleh MK? Dengan lahirnya putusan $M K$, Pemerintah kemudian mengeluarkan PP No. 17 Tahun 2005 tentang Perubahan Atas PP No. 6 Tahun 2005 tentang Pemilihan,

\footnotetext{
${ }^{2}$ Kompas, 23 Maret 2004.

${ }^{3}$ Media Indonesia, 23 Maret 2005

"Lihat Refly Harun, "MK Gagal Mengawal Demokrasi", Kompas, 30 Maret 2005, HIm. 5.
} 
Pengesahan, Pengangkatan, dan Pemberhentian Kepala Daerah dan Wakil Kepala Daerah.

Makalah ini akan membahas aspek yuridis dari sengketa hasil pemilihan kepala daerah secara langsung, khususnya untuk kasus pilkada Kota Depok. Kasus ini menarik dikaji karena sudah menyita perhatian publik berkaitan tarik menarik antara hukum dan politik.

\section{Sengketa Pilkada menurut Perundang- undangan}

Meskipun cita negara hukum telah lahir sekian abad yang lalu, tetapi untuk mewujudkannya dalam kehidupan bernegara hingga saat ini bukanlah persoalan yang mudah. Dalam perkembangannya, terdapat korelasi yang jelas antara negara hukum yang bertumpu pada konstitusi, dengan kedaulatan rakyat yang dijalankan melalui sistem demokrasi. Dalam sistem demokrasi, partisipasi rakyat merupakan esensi dari sistem ini. Dengan kata lain, negara harus ditopang dengan sistem demokrasi. Demokrasi tanpa pengaturan hukum akan kehilangan bentuk dan arah, sedangkan hukum tanpa demokrasi akan kehilangan makna. Demokrasi merupakan cara paling aman untuk mempertahankan kontrol atas negara hukum. ${ }^{5}$

Dalam perkembangannya, paham negara hukum tidak dapat dipisahkan dari paham kerakyatan. Sebab pada akhirnya, hukum yang mengatur dan membatasi kekuasaan negara atau pemerintah diartikan sebagai hukum yang dibuat atas dasar kekuasaan atau kedaulatan rakyat. Begitu eratnya tali-temali antara paham negara hukum dan kerakyatan, sehingga ada sebutan negara hukum yang demokratis atau democratische rechtsstaat. ${ }^{6}$ Dalam kaitannya dengan negara hukum, kedaulatan rakyat merupakan unsur material negara hukum, disamping masalah kesejahteraan rakyat. ${ }^{\text {? }}$

Di negara-negara Eropa Kontinental konsepsi negara hukum mengalami perkembangan yang cukup pesat, utamanya perkembangan terhadap asas legalitas yang semula diartikan sebagai pemerintahan berdasarkan atas undang-undang (wetmatigheid van bestuur), kemudian berkembang menjadi pemerintahan berdasarkan atas hukum (rechtmatigheid van bestuur). Terjadinya perkembangan konsepsi tersebut merupakan konsekuensi dari perkembangan konsepsi negara hukum materiil, sehingga kepada pemerintah diserahi tugas dan tanggungjawab yang semakin berat dan besar untuk meningkatkan kesejahteraan warganya. Akhirnya, kepada pemerintah diberikan pula ruang gerak yang semakin longgar yang cenderung melahirkan pemerintahan bebas ( $v r i)$ bestuur) dengan disertai ruang kebijaksanaan yang longgar berupa freies ermessen. ${ }^{8}$

Asas legalitas berkaitan erat dengan

${ }_{5}^{5}$ Frans Magnis Suseno, Mencari sosok Demokrasi, Sebuah Telaah Filosofis, Gramedia, Jakarta, 1997, HIm. 58.

${ }^{6}$ D.J. Elzinga, "De Democratische Rechtsstaat Als Ontwikkeling Perspectief", dalam Scheltema (ed.), De Rechtsstaat Herdacht, W.E.J. Tjeenk Willink, Zwolle, 1989, HIm. 43. Dikutip kembali dalam Bagir Manan, Hubungan Antara Pusat dan Daerah Menurut UUD 1945, Sinar Harapan, Jakarta, 1994, HIm.167.

${ }^{7}$ Elzinga, Op.Cit., Him. 48.

- SF. Marbun, Eksistensi Asas-asas Umum Penyelenggaraan Pemerintahan Yang Layak Dalam Menjelmakan Pemerintahan Yang Baik dan Bersih Dilndonesia, Disertasi, Program Pascasarjana UNPAD, Bandung, 2001, HIm. 22. Lihat juga dalam Anna Erlyana, Keputusan Presiden Analisis Keppres Rl 1987-1998, Pascasarjana Fakultas Hukum Universitas Indonesia, Jakarta, 2004, HIm. 3-4. 
gagasan demokrasi dan gagasan negara hukum (het democratish ideal en het rechtsstaats idea). Gagasann demokrasi menuntut agar setiap bentuk undang-undang dan berbagai keputusan mendapatkan persetujuan dari wakil rakyat dan sebanyak mungkin memperhatikan kepentingan rakyat. Gagasan negara hukum menuntut agar penyelenggaraan kenegaraan dan pemerintahan harus didasarkan pada undang-undang dan memberikan jaminan terhadap hak-hak dasar rakyat yang tertuang dalam undang-undang. ${ }^{9}$

Penegasan Indonesia adalah negara hukum yang selama ini diatur dalam Penjelasan UUD 1945, dalam Perubahan UUD 1945 telah diangkat ke dalam UUD 1945 Pasal 1 ayat (3), berbunyi sebagai berikut: "Negara Indonesia adalah negara hukum". Konsekuensi ketentuan ini adalah bahwa setiap sikap, kebijakan, dan perilaku alat negara dan penduduk harus berdasar dan sesuai dengan hukum. Sekaligus ketentuan ini untuk mencegah terjadinya kesewenangwenangan dan arogansi kekuasaan, baik yang dilakukan oleh alat negara maupun penduduk.

Sebagus apapun sebuah negara yang ditata secara demokratis tidak akan dianggap benar-benar demokratis manakala pemimpinpemimpinnya tidak dipilih secara bebas oleh rakyatnya sendiri. Pemilihan selalu menjadi tolok ukur sebuah negara demokratis atau tidak. Demokrasi memang tidak semata-mata ditentukan oleh ada tidaknya pemilihan oleh rakyat atas pemimpin-pemimpinnya. Pemilihan memerlukan perangkat lain untuk mendukung proses pemilihan. ${ }^{10}$

Secara umum dikatakan bahwa pemilihan kepala daerah secara langsung itu lebih demokratis. Setidaknya ada dua alasan mengapa gagasan pemilihan langsung dianggap perlu. Pertama, untuk lebih membuka pintu bagi tampilnya kepala daerah yang sesuai dengan kehendak mayoritas rakyat sendiri. Kedua, untuk menjaga stabilitas pemerintahan agar tidak mudah dijatuhkan di tengah jalan.

Sistem pemilihan secara langsung sebagaimana ditawarkan UU No. 32 Tahun 2004 dipandang sebagai solusi terhadap sistem yang lama (UU No. 22 Tahun 1999), karena DPRD tidak lagi berwenang memilih kepala daerah sehingga peluang DPRD untuk bisa 'menjatuhkan' kepala daerah tidak akan semudah sebelumnya. Ada lembaga lain yang akan terlibat dalam proses tersebut yakni lembaga peradilan.

Hal lain yang dimunculkan dalam UU No. 32 Tahun 2004 adalah masalah perselisihan hasil Pemilu. Sebagaimana diketahui, setelah adanya perubahan UUD 1945 muncul lembaga baru yang bernama Mahkamah Konstitusi (MK), yang salah satu wewenangnya adalah memutus perselisihan tentang hasil pemilihan umum. Bagaimana dengan perselisihan hasil Pemilihan Kepala Daerah? Di dalam Pasal 106 UU No. 32 Tahun 2004 ditegaskan:

(1) Keberatan terhadap penetapan hasil pemilihan Kepala Daerah dan Wakil Kepala Daerah hanya dapat diajukan oleh pasangan calon kepada Mahkamah Agung dalam waktu paling lambat 3 (tiga) hari setelah penetapan hasil pemilihan

${ }^{9}$ Ridwan HR, Hukum Administrasi Negara, UII Press, Yogyakarta, 2002, Him. 68-69.

${ }^{10}$ Jimly Asshiddiqie, "Pemilihan Langsung Presiden dan Wakil:Presiden", Jurnal UNISIANo. 51/XXVIIIII 2004, HIm. 10. 
Kepala Daerah dan Wakil Kepala Daerah.

(2) Keberatan sebagaimana dimaksud pada ayat (1) hanya berkenaan dengan hasil penghitungan suara yang mempengaruhi terpilihnya pasangan calon.

(3) Pengajuan keberatan kepada Mahkamah Agung sebagaimana dimaksud pada ayat (1) disampaikan kepada Pengadilan Tinggi untuk pemilihan Kepala Daerah dan Wakil Kepala Daerah Provinsi dan kepada Pengadilan Negeri untuk pemilihan Kepala Daerah dan Wakil Kepala Daerah Kabupaten/Kota.

(4) Mahkamah Agung memutus sengketa hasil penghitungan suara sebagaimana dimaksud pada ayat (1) dan ayat (2) paling lambat 14 (empat belas) hari sejak diterimanya permohonan keberatan oleh Pengadilan Negeri/Pengadilan Tinggi/ Mahkamah Agung.

(5) Putusan Mahkamah Agung sebagaimana dimaksud pada ayat (4) bersifat final dan mengikat.

(6) Mahkamah agung dalam melaksanakan kewenangannya sebagaimana dimaksud pada ayat (1) dapat mendelegasikan kepada Pengadilan Tinggi untuk memutus sengketa hasil perhitungan suara pemilihan kepala daerah dan wakil kepala daerah kabupaten dan kota.

(7) Putusan Pengadilan tinggi sebagaimana dimaksud pada ayat (6) bersifat final. ${ }^{11}$

Dari penegasan di atas, nampak bahwa Mahkamah Agung telah mendapat tambahan wewenang melalui UU No. 32 Tahun 2004, yakni menyelesaikan perselisihan hasil Pilkada. Materi yang dapat disengketakan hanya berkenaan dengan hasil penghitungan suara yang mempengaruhi terpilihnya pasangan calon. Putusan Mahkamah Agung bersifat final dan mengikat, sedangkan putusan Pengadilan Tinggi bersifat final.

Kemudian, perihal sengketa hasil Pilkada juga diatur dalam PP No. 6 Tahun 2005 Pasal 87 sebagai berikut:

(1) Dalam hal pemilihan BupatiWakil bupati dan Walikota/Wakil Walikota, setelah membuat berita acara dan rekapitulasi hasil penghitungan suara sebagaimana dimaksud pada Pasal 86 ayat (5), selambat-lambatnya 1 (satu) hari diputuskan dalam pleno KPUD kabupaten/kota untuk menetapkan pasangan calon terpilih.

(2) Penetapan pasangan calon terpilih sebagaimana dimaksud pada ayat (1), disampaikan kepada DPRD kabupaten/ kota setelah jangka waktu 3 (tiga) hari.

(3) Apabila ada pengajuan keberatan terhadap hasil pemilihan oleh pasangan calon lainnya kepada Mahkamah Agung, KPUD menyampaikan pemberitahuan kepada DPRD kabupaten/kota adanya keberatan tersebut.

(4) Setelah adanya keputusan Mahkamah Agung terhadap pengajuan keberatan sebagaimana dimaksud pada ayat (3), KPUD menyampaikan penetapan pasangan terpilih dan putusan tersebut

${ }^{11}$ Penjelasan Pasal 106 ayat (7) menyatakan, putusan pengadilan tinggiyang bersifat final dalam ketentuan ini adalah putusan pengadilan tinggi yang telah memperoleh kekuatan hukum tetap dan tidakbisa lagi ditempuh upaya hukum. 
selambat-lambatnya 3 (tiga) hari setelah putusan dijatuhkan.

Terhadap adanya keberatan dari calon pasangan lain, Pasal 94 menegaskan sebagai berikut:

(1) Keberatan terhadap penetapan hasil pemilihan Kepala Daerah dan Wakil Kepala Daerah hanya dapat diajukan oleh pasangan calon kepada Mahkamah Agung dalam waktu paling lambat 3 (tiga) hari setelah penetapan hasil pemilihan.

(2) Keberatan sebagaimana dimaksud pada ayat (1) hanya berkenaan dengan hasil penghitungan suara yang mempengaruhi terpilihnya pasangan calon.

(3) Pengajuan keberatan kepada Mahkamah Agung sebagaimana dimaksud pada ayat (1) dapat disampaikan melalui Pengadilan Tinggi untuk pemilhan Gubenur dan Wakil Gubernur dan Pengadilan Negeri untuk pemilihan BupatiWakil Bupati dan Walikọta/ Wakil Walikota.

(4) Mahkamah Agung memutus sengketa hasil penghitungan suara sebagaimana dimaksud pada ayat (1) dan ayat (2) paling lambat 14 (empat belas) hari sejak diterimanya permohonan keberatan oleh Pengadilan Negeri/Pengadilan Tinggi/Mahkamah Agung.

(5) Putusan Mahkamah Agung sebagaimana dimaksud pada ayat (4) bersifat final dan mengikat.

(6) Mahkamah Agung dalam melaksanakan ketentuan sebagaimana dimaksud pada ayat (1) dapat mendelegasikan kewenangannya kepada Pengadilan Tinggi untuk memutus sengketa hasil perhitungan suara pemilihan Bupati/Wakil Bupati dan Walikota/Wakil Walikota.

(7) Putusan Pengadilan Tinggi sebagaimana dimaksud pada ayat (6) bersifat final dan mengikat.

Dengan mengikuti alur pikir perundangundangan perihal sengketa hasil pemilihan kepala daerah, nampak bahwa ada "penyelewengan" di dalam Pasal 94 ayat (7) PP No. 6 Tahun 2005 terhadap amanat UU No. 32 Tahun 2004 Pasal 106 ayat (7), karena menurut UU No. 32 Tahun 2004 Pasal 106 ayat (7) putusan PT hanya bersifat final, sementara dalam PP No. 6 Tahun 2005 Pasal 94 ayat (7) dikatakan putusan PT bersifat final dan mengikat. Secara akademis dapat dikatakan bahwa adanya apabila ada pertentanaan antara bunyi dalam PP dengan UU, maka yang harus dipakai sebagai pedoman yuridis adalah peraturan yang kedudukannya lebih tinggi, dalam hal ini adalah UU No. 32 Tahun 2004.

Untuk mengatur lebih lanjut tata cara pengajuan upaya hukum keberatan terhadap penetapan hasil pilkada dan pilwakada dari KPUD Propinsi dan KPUD Kabupaten/Kota, Mahkamah Agung mengeluarkan Peraturan Mahkamah Agung RI No. 01 Tahun 2005. Dalam Pasal 1 ditegaskan bahwa yang dimaksud dengan keberatan adalah upaya hukum bagi pasangan calon kepala daerah dan calon wakil kepala daerah, yang tidak menyetujui penetapan hasil perhitungan suara tahap akhir pemilihan kepala daerah dan wakil kepala daerah dari Komisi Pemilihan Umum Daerah. Pemohon adalah pasangan calon kepala daerah dan calon wakil kepala daerah tingkat propinsi maupun tingkat kabupaten/ kota. Termohon adalah KPUD tingkat propinsi atau KPUD tingkat kabupaten/kota.

Di dalam Pasal 2 ayat (4) dan ayat (5) PERMA No. 01 Tahun 2005 ternyata juga mewarisi penyelewengan yang telah dilakukan oleh PP No. 6 Tahun 2005, karena rumusannya 
ambigu. Dinyatakan dalam Ayat (4), Mahkamah Agung atau Pengadilan Tinggi memutus permohonan keberatan pada tingkat pertama dan terkahir. Kemudian ayat (5) menegaskan, Putusan Mahkamah Agung atau Pengadilan Tinggi bersifat final dan mengikat.

Kalau kita kembali ke dasar pengaturan dalam UU No. 32 Tahun 2004, maka harus dibedakan secara tegas sifat putusan antara Pengadilan Tinggi dan Mahkamah Agung. Ketentuan dalam Pasal 106 ayat (5) secara tegas menyatakan, putusan Mahkamah Agung bersifat final dan mengikat. Sedangkan putusan Pengadilan Tinggi bersifat final (Ayat (7)).

Tata cara pengajuan upaya hukum keberatan terhadap hasil perhitungan suara sebagaimana diatur dalam Pasal 3 PERMA No. 6 Tahun 2005 sebagai berikut:

(1) Keberatan terhadap penetapan hasil pemilihan Kepala Daerah dan Wakil Kepala Daerah hanya dapat diajukan berkenaan dengan hasil penghitungan suara yang mempengaruhi terpilihnya pasangan calon;

(2) Keberatan sebagaimana yang dimaksud dalam ayat (1) diajukan kepada Mahkamah Agung atau melalui Pengadilan Tinggi paling lambat 3 (tiga) hari setelah penetapan hasil akhir pemilihan Kepala Daerah dan Wakil Kepala Daerah;

(3) Keberatan pasangan calon terhadap penetapan KPUD Kabupaten/Kota, diajukan kepada Pengadilan Tinggi melalui Pengadilan Negeri paling lambat 3 (tiga) hari setelah penetapan hasil akhir pemilihan Kepala Daerah dan Wakil Kepala Daerah;

(4) Keberatan ditandatangani oleh pemohon atau kuasa hukum dengan dilengkapi bukti-bukti pendukung, baik asli atau foto copy yang telah dilegalisasi dan dibuat dalam rangkap 7 (tujuh) exemplar;

(5) Keberatan yang diajukan oleh pemohon atau kuasa hukumnya wajib menguraikan dengan jelas dan rinci tentang:

a. Kesalahan dari perhitungan suara yang diumumkan oleh KPUD dan hasil perhitungan suara yang benar menurut pemohon;

b. Permintaan untuk membatalkan hasil perhitungan suara yang diumumkan KPUD dan menetapkan hasil perhitungan suara yang benar menurut pemohon.

(6) Setelah permohonan diterima Mahkamah Agung atau Pengadilan Tinggi secepatnya memeriksa keberatan dimaksud dan memerintahkannya dalam waktu paling lambat 14 (empat belas) hari;

(7) Persidangan Mahkamah Agung dilakukan oleh Majelis Hakim yang terdiri dari 5 (lima) orang Hakim Agung, dan persidangan Pengadilan Tinggi dilakukan oleh majelis hakim yang terdiri dari 3 (tiga) orang Hakim tinggi. Pemeriksaan dilakukan atas berkas perkara;

(8) Mahkamah Agung dapat memanggil para pihak untuk didengar keterangannya, bilamana dipandang perlu;

(9) Dalam hal diperlukan pemeriksaan setempat, Mahkamah Agung atau Pengadilan Tinggi memerintahkan Pengadilan Tinggi/Pengadilan negeri melakukan pemeriksaan. Pemeriksaan sudah selesai paling lambat 3 (tiga) hari sejak perintah diterima. 


\section{Kasus Pilkada Kota Depok}

Mempelajari kasus yang terjadi dalam Pilkada Depok setidaknya dapat kita temukan beberapa hal menarik: Pertama, titik tolak yang dipakai sebagai alasan Pemohon (Drs.H. Badrul Kamal, MM dan KH. Syihabuddin Achmad, BA) dalam permohonan keberatan berkaitan dengan masalah jumlah daftar pemilih tetap. Menurut Pemohon, jumlah daftar pemilih tetap Kota Depok adalah 899.419 orang, tetapi menurut Pemohon ada sejumlah orang yang tidak berhak memilih (9.471 orang) dilegalkan melalui Keputusan KPUD Kota Depok dengan menganulir daftar pemilih tetap, yang ternyata menurut pemohon orang-orang tersebut adalah pendukung pasangan calon No. 5 (Nur Mahmudi dan Yuyun S). Disamping itu, ada 37.253 orang yang tidak berhak memilih (bukan penduduk dan bukan pemilih) tetapi hanya menumpang (kontrak/kos) diberi undangan untuk memilih dan mendukung pasangan calon No. 5 . Jumlah suara yang ada pada Penetapan Komisi Pemilihan Umum Kota depok adalah 549.992 orang. Jumlah sisa suara yang tidak diperbolehkan menggunakan hak pilihnya adalah 899.419-549.992 $=349.427$. Adapun jumlah suara yang sebenarnya mendukung pasangan calon No. 5 adalah 232.610-37.253 $=195.357$. Untuk mendukung asumsi Pemohon disampaikan sejumlah bukti dan saksi, yang akhimya Pemohon menyimpulkan bahwa ada 62.750 suara bagi Pemohon, namun hilang karena dihalang-halangi untuk memberikan suaranya sehingga perolehan suara yang sebenarnya untuk Pemohon sebanyak 269.531 suara. Sedangkan perolehan suara calon No. 5 yang sebenarnya adalah 232.610-37.253 =
195.357 suara. $^{10}$ Dapatkah diketahui secara pasti bahwa jumlah suara yang dipertanyakan itu (illegal) adalah memilih calon No.5 atau sebaliknya calon No. 3 ?

Kedua, Permohonan Keberatan yang diajukan oleh Pemohon ke Pengadilan Negeri Cibining dan Pengadilan Tinggi Bandung pada tanggal 12 Juli 2005, sementara penetapan hasil pemilihan Walikota dan Wakil Walikota Depok dilakukan pada tanggal 06 Juli 2005. UU No. 32 Tahun 2004 membatasi pengajuan keberatan terhadap hasil perhitungan suara adalah 3 (tiga) hari setelah penetapan hasil pemilihan kepala daerah dan wakil kepala daerah. Sehingga permohonan keberatan itu harus ditolak karena sudah melampaui tenggang waktu yang ditentukan oleh UU.

Ketiga, putusan Pengadilan Tinggi yang menganulir hasil Pilkada Kota Depok apakah bersifat final ataukah final dan mengikat? Polemik yang muncul di masyarakat menyatakan bahwa putusan Pengadilan Tinggi Bandung bersifat final dan mengikat sehingga tidak ada lagi upaya hukum. Kembali ke dasar hukum UU No. 32 tahun 2004 Pasal 106 ayat (7), jelas dinyatakan bahwa putusan Pengadilan tinggi bersifat final, sehingga Termohon (KPU Depok) masih dapat mengajukan upaya hukum ke Mahkamah Agung karena putusan akhir ada pada Mahkamah Agung. Persoalan yang muncul kemudian, berapa lama Mahkamah Agung harus memberikan putusan akhir apabila putusan Pengadilan Tinggi ditolak oleh KPUD, tidak ada pengaturannya secara tegas, baik dalam UU No. 32 tahun 2004, PP No. 6 Tahun 2005 ataupun PERMA No. 1 Tahun 2005. Seharusnya untuk Pilkada

\footnotetext{
${ }^{10}$ Putusan No. 01/PILKADA2005?PT.BDG.
} 
ada penagturan masalah ini secara tegas, supaya tidak berlarut-larut terjadi kevakuman pimpinan di daerah.

Jika kita memakai UU No. 14 Tahun 1985 tentang Mahkamah Agung, dalam Pasal 69 ditegaskan bahwa tenggang waktu pengajuan permohonan peninjauan kembali adalah 180 (seratus delapan puluh) hari. Pasal 72 menegaskan, Panitera berkewajiban untuk selambat-lambatnya dalam waktu 14 (empat belas) hari memberikan atau mengirimkan salinan permohonan tersebut kepada pihak lawan pemohon. Tenggang waktu bagi pihak lawan untuk mengajukan jawabannya adalah 30 (tiga puluh) hari setelah tanggal diterimanya salinan permohonan peninjauan kembali. Surat jawaban diserahkan atau dikirimkan kepada Pengadilan yang memutus perkara dalam tingkat pertama. Oleh Panitera permohonan tersebut dikirimkan kepada Mahkamah agung selambat-lambatnya dalam jangka waktu 30 (tiga puluh) hari.

Dalam hal Mahkamah Agung mengabulkan permohonan peninjauan kembali, Mahkamah Agung membatalkan putusan yang dimohonkan peninjauan kembali tersebut dan selanjutnya memeriksa serta memutus sendiri perkaranya. Mahkamah agung mengirimkan salinan putusan atas permohonan peninjauan kembali kepada Pengadilan negeri yang memutus perkara dalam tingkat pertama dan selanjutnya Panitera Pengadilan Negeri yang bersangkutan menyampaikan salinan putusan itu kepada pemohon serta memberitahukan putusan itu kepada pihak ;awan dengan memberikan salinannya, selambat-lambatnya dalam waktu 30 (tiga puluh) hari. Ternyata UU No. 14 Tahun 1985 juga tidak memberi batasan yang tegas berapa lama waktu yang dibutuhkan oleh Mahkamah Agung untuk memutuskan permohonan peninjauan kembali.

Ada hikmah yang sangat berharga dari peristiwa Pilkada Depok, bahwa menyelenggarakan Pilkada bukanlah pekerjaan yang mudah dan ringan, hajatan itu bersinggungan langsung dengan masyarakat di bawah, sehingga butuh kerjasama antar berbagai pihak, baik calon, KPUD, Panwasda, Saksi, petugas di lapangan, media massa, dan masyarakat.

Penyelenggaraan Pilkada bukan hanya mempertaruhkan kredibilitas KPUD di mata publik tetapi juga lembaga peradilan manakala dalam penetapan hasil perhitungan suara timbul konflik (sengketa). Maka, dengan berpegang pada prinsip negara hukum, konflik politik harus bisa diselesaikan oleh hukum. Baik KPUD maupun Pengadilan harus independen dan profesional dalam mengemban tugas dan wewenangnya.

\section{Penutup}

Dari uraian di atas kiranya dapat disimpulkan bahwa pengaturan pemilihan kepala daerah secara langsung melalui UU No. 32 Tahun 2004 masih banyak mengandung cacat yuridis, karena ketidakjelasan konsep dari UU tersebut Putusan MK tentang pemilih-an kepala daerah secara langsung yang menyatakan KPUD tidak bertanggungjawab kepada DPRD tetapi kepada rakyat, bukannya menyelesaikan persoalan tetapi menambah persoalan baru. MK pun terjebak pada "pesan sponsor" UU No. 32 Tahun 2004 yang mendisain Pilkada ini bukan pemilu. Seandainya putusan MK menyambungkan kembali hubungan KPUD dengan KPU sebagaimana diatur dalam UU No. 12 Tahun 
2003, maka keruwetan pengaturan Pilkada akan berkurang.

Masalah pengaturan Pilkada yang "amburadul" ini menjadi pelajaran yang sangat berharga bagi kita, agar kelak di kemudian hari Pemerintah dan DPR tidak "tergesa-gesa dan memaksakan diri" untuk mengatur sesuatu tanpa didahului dengan pengkajian yang mendalam. Jangan terlalu berharap demokrasi akan lahir dari kerja yang "acakacakan" di negara hukum Indonesia. Melahirkan negara hukum yang demokratis adalah pekerjaan serius dan butuh bingkai yuridis yang jelas dan tegas.

\section{Daftar Pustaka}

Anna Erliyana, Keputusan Presiden Analisis Keppres Rl 1987-1998, Pascasarjana Fakultas Hukum Universitas Indonesia, Jakarta, 2004

Bagir Manan, Hubungan Antara Pusat dan Daerah Menurut UUD 1945, Sinar Harapan, Jakarta, 1994.

Frans Magnis Suseno, Mencari Sosok Demokrasi, Sebuah Telaah Filosofis, Gramedia, Jakarta, 1997.

Ni'matul Huda, Otonomi Daerah, Filosofi, Sejarah Perkembangan dan Problematika, Pustaka Pelajar, Yogyakarta, 2005.
MPR RI, Panduan Dalam Memasyarakatkan UUD Negara Republik Indonesia Tahun 1945, Sekretariat Jenderal MPR Rl, Jakarta, 2003.

Ridwan HR, Hukum Administrasi Negara, UII Press, Yogyakarta, 2002.

SF. Marbun, Eksistensi Asas-asas Umum Penyelenggaraan Pemerintahan Yang Layak Dalam Menjelmakan Pemerintah-an Yang Baik dan Bersih Di Indonesia, Disertasi, Program Pascasarjana UNPAD, Bandung, 2001. Jurnal UNISIA No. 51/XXVII///2004.

Kompas, 4 Pebruari 2005.

Media Indonesia, 23 Maret 2005

Kompas, 30 Maret 2005

Kompas, 23 Maret 2005.

UU No. 22 Tahun 1999 tentang Pemerintahan Daerah.

UU No. 32 Tahun 2004 tentang Pemerintahan Daerah.

PP No. 6 Tahun 2005 tentang Pemilihan, Pengesahan, Pengangkatan, dan Pemberhentian Kepala Daerah dan Wakil Kepala Daerah.

Peraturan Mahkamah Agung Ri Nomor 01 Tahun 2005 tentang Tata Cara Pengajuan Upaya Hukum Keberatan terhadap Penetapan Hasil Pilkada dan Pilwakada dari KPUD Propinsi dan KPUD Kabupaten/Kota. 